\title{
Local pre-industrial communities in Tuscany and the exploitation of water
}

\author{
D. Ulivieri \\ Department of Civilizations and Forms of Knowledge, University of Pisa, Italy
}

\begin{abstract}
Since the middle ages, local communities which were able to channel water, organized water powered manufactories and mills, creating over time what were actual "pre-industrial districts", indivisibly bound to the network of channels that drove the vertical or horizontal blades of the millwheel. Canals, watercourses and waterfalls were as much as factor of production as the land and iron, coal and silver mines, and with time, communities learned to exploit water power with increasing efficiency. Water is by its very nature highly dynamic, and as a consequence, since ancient times, human activity has been directed at taking advantage of it power. The Tuscan case studies in point - Calci (Pisa), Rio dell'Elba (Livorno) and Colle di Val d'Elsa (Siena) - still legible on the land, even if confusedly, vouch for the value of the work culture and that of the land and environment, which belong by right to the resident community.
\end{abstract}

\section{INTRODUCTION}

The harnessing of animal, water and wind power and the conversion of the resultant motive power to drive millstones, fulling stocks, weaving and textile machines, saws, pumps and the whole range of crushers, grinders and mixers resulted in a significant increase in productivity, which in turn helped sustain a greatly increased and growing population (Oliver 1997).

In Tuscany the prevalent system of social organization was based on village economies, that is, managed by small, usually self-consuming communities, tied to local, intensive forms of transformation of the original nature of the land - terracing, for example Pierotti \& Ulivieri (2009).

A system of management of runoff waters was organized in Tuscany's mountain and hill areas, but also on stretches of river in the valleys, adapting it to the different features of the land and the morphology of the soil. Beginning mainly in the Middle Ages, natural and artificial water courses constituted the energy source that powered the different kinds of mill widespread throughout the towns and countryside. Agricultural activities integrated with those of a semi-industrial nature, and both needed a continual supply of water.

Water, especially if channelled with the right declivity for repeated "falls", constituted an inexhaustible source of motive power for use in numerous activities, and to drive devices of various sizes and types. Ditches, watercourses and waterfalls were a factor of production like land, or iron, coal or silver mines. Local communities learned to take advantage of hydropower. Communities, therefore, undertook to make the water systems efficient and prevent embankments and levies from collapsing. To strengthen these wealth-creating production systems, a series of specific regulations regarding water management was introduced.

Historic Tuscan water regulations show a series of similarities and continuity with the provisions of local by-laws concerning rivers and canals, the "free flow of Rivers" and the "maintenance of their Banks". The Grand Duchy's policy regarding the supervision of water courses was not far removed from the numerous provisions included in the bylaws of local communities (Ulivieri 2009).

\section{THE ECO-HISTORY METHOD}

Eco-history reconstructs the history of peoples without history, those ignored by official sources, but who left evidence of their existence and their culture in a material product. Ecohistory is the history of the oikos, that is, the history of human settlements however they were formed.

The neologism was coined on the fringes of an international, multidisciplinary conference promoted by Piero Pierotti and organized in Lucca in 1975, for the purpose of grouping together studies on the his- 
tory of cities and territories. During discussions, an invitation was made to find a common term that defined this vast field of study. Thus it was that the term "eco-history" was introduced. In this word, the prefix eco- was derived strictly from its etymological meaning (oî́kos [òicos], that is, house or dwelling place) (Pierotti 1982).

A home or dwelling place is one of man's primary needs: this is the basic concept assumed as a guideline. The field of application of ecohistory encompasses homes, places of work, communication routes, landscape and environment: in practice, the whole system of changes made by man to his environment to shape it into a habitable place, usable for his purposes. Since the beginning of time, the culture of a dwelling place has belonged to individuals or individual communities which were probably not in the habit of rubber stamping plans, and almost certainly did not design their cities on paper. If they have left visible traces in their ways of building and of adapting the spaces they inhabited, these are documents for eco-history (Pierotti 1999).

Eco-history relates, therefore, to the study of material culture, anthropology, archaeology and, more specifically, vernacular architecture.

The eco-history method was therefore applied to analyse local communities who left evidence of their passage and their culture in a material product. In particular, this study examines those communities that based their economy on the exploitation of the land and water sources.

Case studies on the Calci valley, a short distance from Pisa, where the waters of the Zambra torrent were harnessed, the Valley of Watermills in Rio nell'Elba on the biggest island in the Tuscan archipelago, where water captured at the "Canali" spring was channelled towards the coast, or the complex system of "gore" (artificial channels) in Colle di Val d'Elsa, a hill town north-west of Siena, represent just some of the many integrated water usage models still legible throughout Tuscany.

\section{MONTE PISANO AND THE "VALLEGRAZIOSA", CALCI (PISA)}

A network of millponds and artificial channels that carried water from one mill to another (known as a gora, or in the Calci Valley as an aldio), drove the mostly vertical-bladed wheels of the mills and oil presses that carpeted Monte Pisano, which separates the Pisa plain from that of Lucca. Monte Pisano is a small mountain chain that rises abruptly from the lower Arno Valley. To the eyes of a medieval wayfarer, Monte Pisano appeared as isolated between two valleys, circumscribed by two rivers, two canals and a lake, besieged by swamps fed by the waters of the Arno and the Serchio, which totally encircled it (Ulivieri 2006). This area replicated a perfect inter- modal transport system, where goods and passengers travelling by water along the main rivers and canals connecting lakes and swamps, could change carrier and travel overland along cart tracks in the foothills. The area's optimal hydrography, with perennial springs flowing down the slopes of the mountains, also supplied a "precious" resource, the hydropower needed to move the waterwheels of the mills in the villages scattered throughout the territory (Fig. 1).

Calci, "a minute, industrious and wealthy town", "stands almost at the centre of Monte Pisano, in the most eminent position in the valley" cut through by the Zambra torrent (Fig. 2)

Since the Middle Ages, the people of Calci had known how to harness the waters of the Zambra and organized mills "worked by water, creating over time nothing less than a "pre-industrial district" bound inseparably to the network of channels and canals that moved the mostly vertical waterwheels (Ulivieri 2015).

The Calci area was so productive as to be described as Valgraziosa (a valley rich in resources and natural beauty) since the 14th century, not only for the imposing presence of the Charterhouse, but above all for the great number of mills. Most of the mills in Calci had overshot waterwheels, vertical wheels activated by a "fall", over 3 or 4 metres high, with the tallest reaching 12, 13 metres (Chini 2003).

The overshot wheel was turned primarily by the weight of water in the buckets. Overshot wheels required a head of water, invariably achieved by construction of a leat to collect water higher up the stream (Oliver 1997).

In 1865 there were no less than 104 watermills in Calci, arranged along the ridges flanking the steeply descending Zambra torrent, following one after the other, each with its wheel turned by a complex system of channels that derived water from the Zambra (aldium) and conducted it into leats created to feed the mills (aquis ductura, aquiductor, aqueducio, aquiducio, aquiducium).

Brick-lined artificial channels carried water to the mill, where it was directed via waterfalls (gittos de lapidibus et aldios) to the wooden chute from which it fell to hit the blades of the wheel (Panduri 2001).

In 1768, Peter Leopold of Hapsburg-Lorraine noted that "the Zambra river...turns 105 waterwheels, one above the other, which grind all the wheat for Livorno... and the province of Pisa" (D’Asburgo Lorena 1970).

This type of "overshot waterwheel" - sometimes identifiable in some documents as molendinum franceschum (Muendel 1984) - was particularly suited to areas, such as Calci, which featured considerable slopes and abundant water to ensure a good height of fall. The Zambra torrent, in fact, is characterized by a complex water system, which goes from an altitude of 350 metres at the source to 25 metres at the mouth, divided into a succession of gullies that form 
a series of falls and changes in levels in the riverbed (Manetti 1985).

If on one hand, milling was essential for the production of flour, indeed, the so-called "White Art" was one of the mainstays of Calci's economy, on the other hand it is not at all strange that such mills could be adapted to other kinds of production depending on market demands. It was, therefore, usual to flank the old mills for grinding grain with "falls for sharpening" and fulling stocks for the treatment of cloth.

There again, the molinum franceschum, or overshot waterwheel", is also associated with the development of the wool industry and the production of cloth a la francescha - this type of cloth was an "medium" product, of good quality but at a relatively affordable price - which flourished in Pisa from the second half of the 13th century to the $14^{\text {th }}$ century, a period of particular prosperity for the city's industry.

In Calci, however, flour production reached levels far superior to that needed to meet the simple demands of local self-consumption. Grain brought to the nearby towns by sea was taken to be ground in Calci, and sent back to the town in the form of flour (Deri 2015).

The arrival of steam and electrically-operated machines during the early 1900s sealed the fate of this centuries-old activity. Devoid of any kind of protection, in the post-World War II years the mills were demolished, "disassembled" and "redeveloped".

Despite everything, the millstones and gears, the occasional surviving mill and the complex system of channels in the Calci valley still remain as testimony to the area's history.

The complex system of watermills that involved Calci's entire housing system, and which is still legible today, vouch for the value of the work culture and that of the land and environment, which belong by right to the resident community (Fig. 3).

\section{COLLE DI VAL D'ELSA: “DAUGHTER OF WATER"}

In Colle di Val d'Elsa, situated "a little below Florence, a little above Siena" (Maccari 1926), the abundant springs located at the Caldane and the Vene ensured the year-round supply of water to drive the millstones and other mechanisms of the "water-driven edifices" as they were called.

There are different types of gora, or artificial channel in Colle. Some are located in open countryside before the San Marziale Bridge (Le Vene Gora, Calcinaia Gora, Le Nove Gora), about $1.5 \mathrm{~km}$ from the town, others (Maestra Gora, Spugna Gora and Piazza Gora) originate from it and take water into the town. To exploit the perennial waters of the Elsa to the full, a "steccaia", or sluice-gate was built at the foot of the bridge, which served to raise the level of the water and direct it towards the Callone Reale, a small edifice to activate the floodgate (Gelli 2009) (Fig. 4).

The series of canals deriving from the Elsa River, and which formed a complex system of locks, millponds and aqueducts, provided driving power for millstones and fulling stocks for wool or paper, and also for grinding grain and sharpening iron and steel tools (Ninci 2002).

Colle, "daughter of water", is a true "preindustrial district" bound inseparably to the series of canals deriving from the Elsa river that make up the complex system of gore, or artificial channels, and provided driving power for millstones and fulling stocks for wool or paper, and also for grinding grain and sharpening iron and steel tools.

All the edifices that benefitted from these gore, or artificial channels, used horizontal water wheels to turn the millstones and other machinery. The waterwheel, located in a chamber beneath the mill, was driven by the fall of water coming from the millpond and channelled into a mill race. The rapid turning of the waterwheel buckets turned the two millstones above. Vertical waterwheels are to be found to a much lesser extent in Colle, and are associated with secondary uses (Gelli 2014).

"Water driven" mills in Colle were so numerous that when the Arno in Florence burst its banks in 1333 and put the city's mills out of action, the people of Colle sent the stricken inhabitants a great quantity of flour for their sustenance.

The production of paper increased to become the main industry in Colle for at least five centuries, so important as to be included in the Town By-Laws from 1307. At the end of the 15th century, paper production was the most socially relevant industry, and in full expansion - by this time, there were at least ten working paper mills. In the following centuries, the role of paper mills as the driving force for Colle's economy became increasingly incisive and exclusive.

From 1311, the Town Council organized the "pruning of the canals", or their periodic cleaning to keep them open and the flow of water constant. Maintenance of the canals on which the "waterdriven edifices" operated was constant and thorough. From one set of bylaws to another, the numerous records of work carried out are more exact, and regulations become more detailed, to the extent of very carefully defining the duties of the curious figure, the guardia gore or Conduttore d'Acqua (the person designated to monitor the canals). These regulations were reiterated until the $20^{\text {th }}$ century, to the extent that the Statuto Regolamento del Consorzio Utenti Gore (the statute and regulations for the canal users consortium) drafted in 1936 implements the 1491 Capitoli sulle acque e sulle gore (Chapters concern- 
ing waters and canals), and proposes the role of Guardia gore - Callonai or Canals and Locks Guard, a descendent of the long-ago "Conduttore d'Acqua", who has more or less the same duties.

The downturn in the paper manufacturing industry, which began around the mid-Nineteenth century, and the introduction in the early 20th century of modern electric turbines in the place of old watermills, led to the inevitable closure of most of Colle's workshops, and from then on, the water served only to irrigate the few remaining orchards. In the 1980s, the last working watermills ceased operation, and in the same years the paper mills also closed their doors. Nonetheless, the canals still continue to flow, even if hidden from sight in many stretches, and some mills (about twenty) still standing, continue to have hope in a not yet near future (Figs 5-6).

\section{RIO NELL'ELBA VALLEY OF WATERMILLS}

The Valley of Watermills winds for about two kilometres, most of it through the Rio nell'Elba municipal area, with just the final part in the Rio Marina area.

Rio nell'Elba, situated three kilometres inland on the eastern side of Elba Island, two hundred metres above sea level on a well-ventilated iron oxide hill, is a maze of stairways and steps. The inhabitants of Rio Alto (its old name), iron ore miners since ancient times, had long known how to exploit the power of water (the oldest document traced that mentions watermills dates back to the mid-16th century).

The Fosso dei Canali is the watercourse that once fed the millponds and thus the succession of watermills that descended from an altitude of 146 metres for the first to 21 metres for the last. During a field study in the summer of 1991 led by Piero Pierotti, in addition to the watermills ( 7 of the 22 watermills had been destroyed, two were used for other purposes, and the rest were abandoned by 1991), and the hydraulic systems, it is possible to identify a series of edifices directly connected with the subject of the valley and the exploitation of water (houses, churches, orchards, gardens, an oven, a wash trough).

A network of 22 watermills in 1,600 metres of valley with a 125 drop in height, with an average of one mill approximately every 73 metres and $5-6$ metres in altitude Pierotti (1993).

They were horizontal waterwheel mills, the type most widespread in Tuscany, less powerful than those with vertical waterwheels (Fig. 7).

The horizontal waterwheel needed small volumes of fast-flowing water to grind modest quantities of grain, and so was tied to domestic production for self-consumption (Cadolini 1835).

The millhouses are simple, compact and functional, with a single millstone, that is, one pair of grinding stones, and mostly consisting of a single room. The watermills of Rio are typified by those functional elements connected with the specific exploitation of water, a millpond, a cistern and a chute, which constitute a clear landscape context to analyse in its entirety. The millponds, placed in succession to act as reservoirs, feeding the millraces and increasing grinding power, were partly used to irrigate crops in the fields. The valley was marked by a network of secondary canals that branched off from the millponds and distributed water to the fields, gardens and orchards, a system that allowed for total recycling of the water. Most of the watermills were concentrated in the upper valley, where declivity was greatest. Here the mills were arranged to the right and left of the Fosso dei Canali, and generally those on the same bank had millponds that filled in succession (Fig. 8).

The last stretch of the valley features a lesser slope, and the watermills, most of which have been destroyed, were located a good distance from each other. The Valley of Watermills, which is now part of the Tuscan Archipelago National Park, has changed. Water is collected at the source and piped towards the coast, the watercourses have been deviated and the dried up millponds are used for crops. Between the Fifties and Seventies, the abandonment of crop growing and of everything connected with farming the land, together with the decline and finally closure of the iron ore mines, led to the desertion of these once-working ruins, which unused, preserve the memory of themselves.

The historical research begun in 1991 has restored a cultural and social sense to the Valley of the Watermills, abandoned and forgotten until then, and has renewed the relationship between the town, the valley and its inhabitants (Fig. 9).

The political will to recover this area and transform it into an eco-museum has often been declared since then, but to date no-one has yet found the key to restoring this heritage to the community.

\section{CONCLUSION}

Three valleys of watermills located in different areas of Tuscany, three integrated water usage models with different characteristics - Calci and Colle closely tied to commercial production and thus to specialized form of industrialization, and Rio nell'Elba, on the other hand, connected to the grinding of grain for domestic self-consumption. The variety of ways of exploiting the dynamic power of water is typical of a region such as Tuscany, where diversity is a collective culture. These models allowed for the total recovery of the water collected, opportunely channelled and fed to the mills through a series of functional elements connected with their particular use, and then returned to the river "pure, fresh and crystal clear". When Colle Val d'Elsa na- 
tive Ferdinando Morozzi (1723-1785), a grand-ducal engineer, expert in hydraulics, mathematics and cartography, was asked in 1775 if the waters of the Borro di Romiccioli in the village of Sant'Agata Mugello "would be muddied" by "a waterwheel for grinding Grain", his irritated reply demanded how "a water that was clear when collected in a millpond and clear when let out" could muddy anything? (Ulivieri 2009). Nevertheless, this subject should not be tackled under the aegis of fogeydom or even less so of nostalgia. It is true, however, that this type of model has become a very topical again because of the question of renewable energy.

Besides, modern wind turbines used to generated clean electricity are increasingly popular, exemplifying that the technology may still have much to contribute to the provision of sustainable future built environments (Vellinga et al. 2007).

Past and present are bound together in continuity, and often opposition is only apparent. An ecohistorical reading of the territory reveals convergences with the present, and suggests the recovery of theoretically obsolete models. After all, it is true that the history of peoples follows a changing course, but basic needs remain the same. This raises the political problem of the so-called re-use of the existing.

Among its aims, the Tuscany Region's territorial plan, which also includes the landscape, includes the "valorisation of the historic-testimonial evidence connected with the water resource and the strongly identifying places along the river, also subsidising for that purpose, projects for the recovery of historic-testimonial artefacts connected with water resources". The public administration's intent should not be limited to the concept of not losing the memory of the "strongly identifying places", but should have a sense of how much and in what way such recovery can be realized, taking a lesson from history and the functionality of such edifices Pierotti \& Ulivieri (2009).

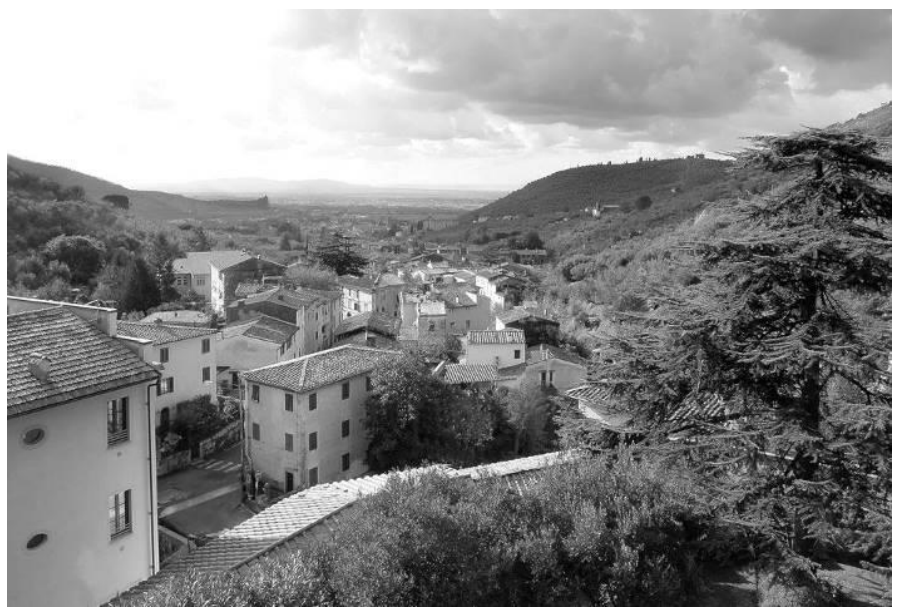

Figure 1. The arrangement of houses in Calci is closely tied to the diffusion of mills (photo by M. Rossi 2015).

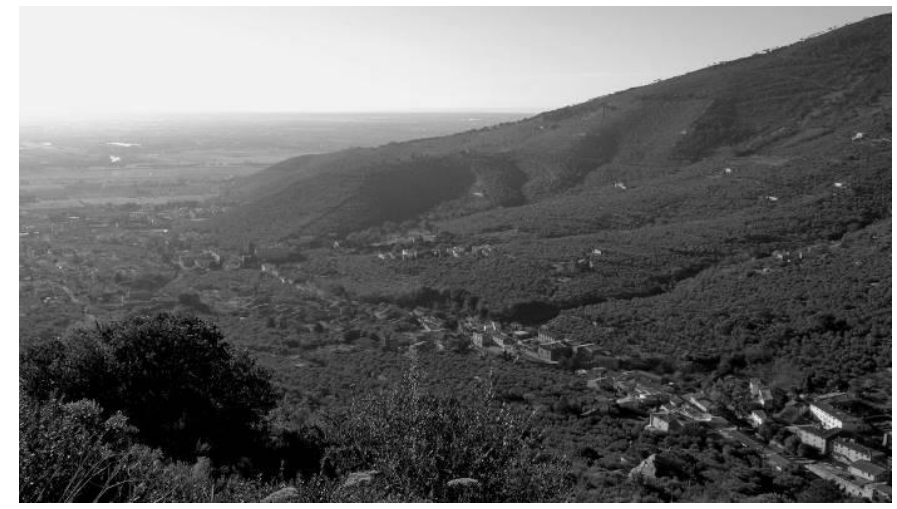

Figure 2. Calci "stands almost at the centre of Monte Pisano, in the most eminent position in the valley" cut through by the Zambra torrent (photo by M. Rossi 2015).

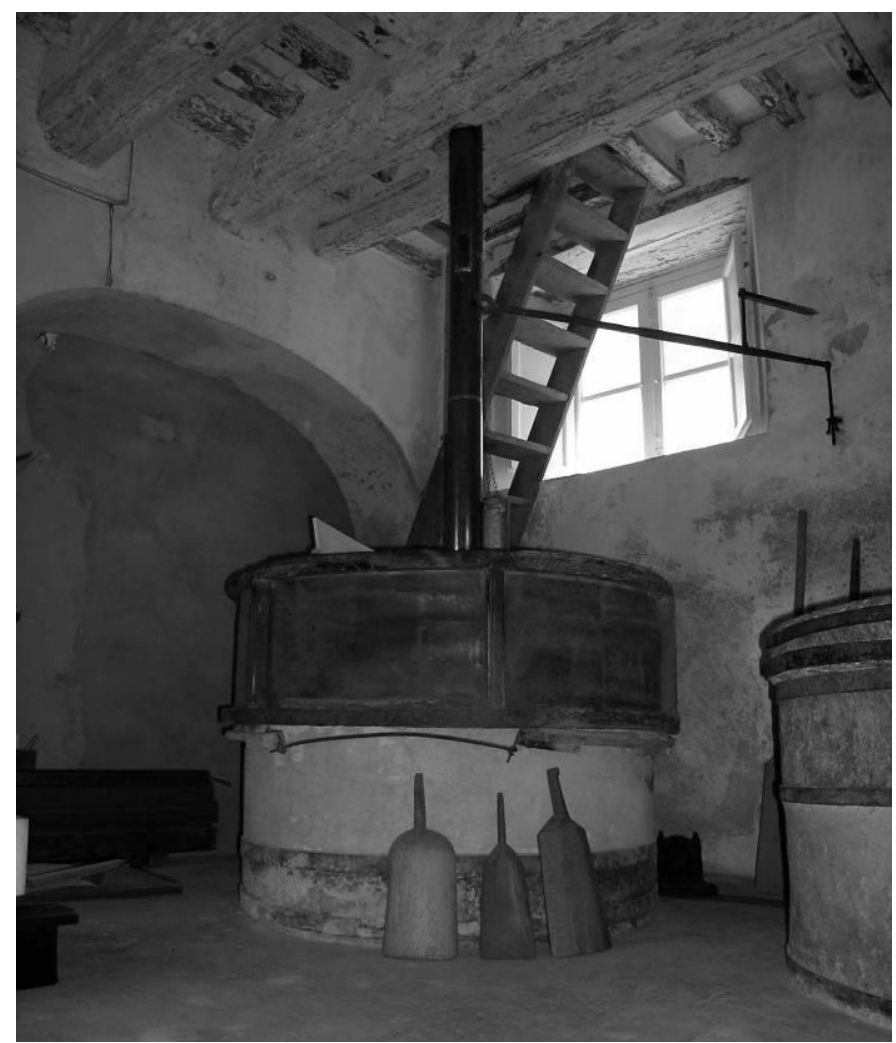

Figure 3. Two of the three millstones from the Gangalandi Mill, Calci (photo by D. Ulivieri 2006).

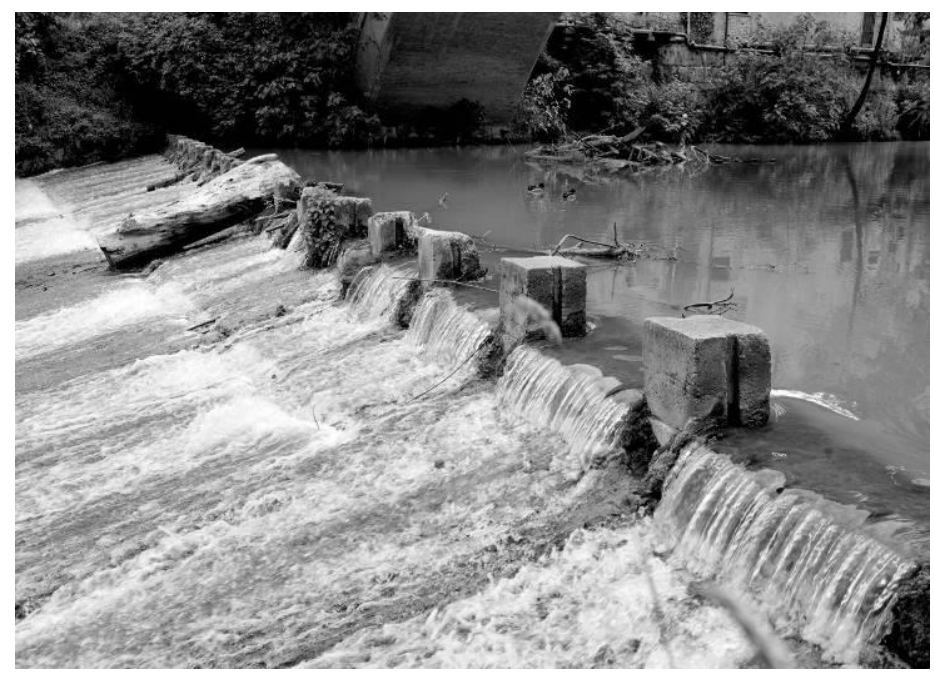

Figure 4. Sluicegate, San Marziale, Colle di Val d'Elsa (photo by F. Spalletti 2014). 


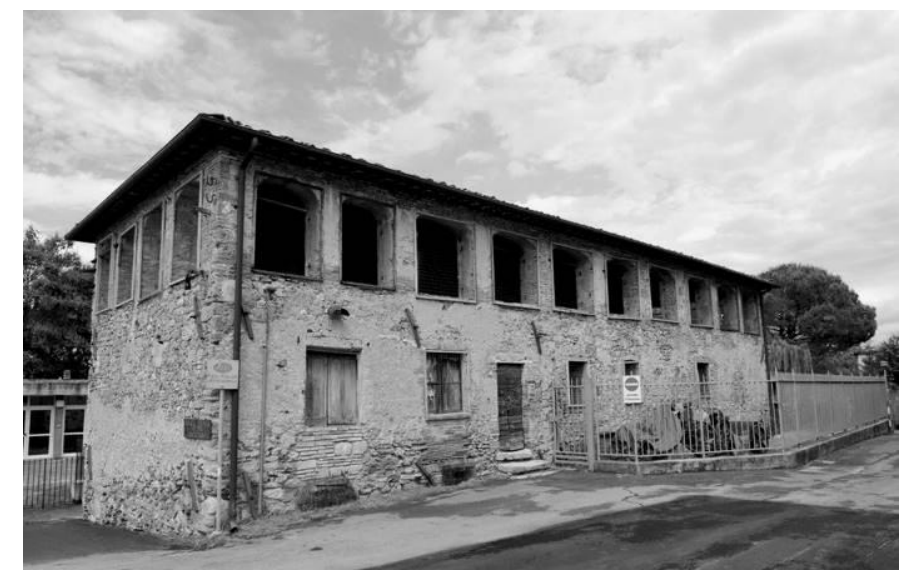

Figure 5. La Buca Paper Mill, Colle di Val d'Elsa (photo by F. Spalletti 2014)

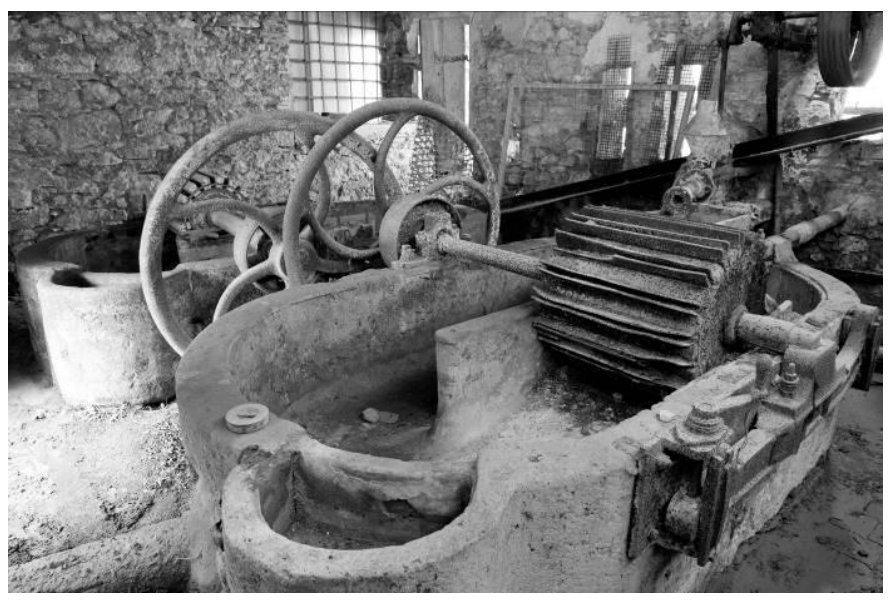

Figure 6 - Machinery for the production of paper, La Buca Paper Mill, Colle di Val d'Elsa (photo by F. Spalletti 2014).

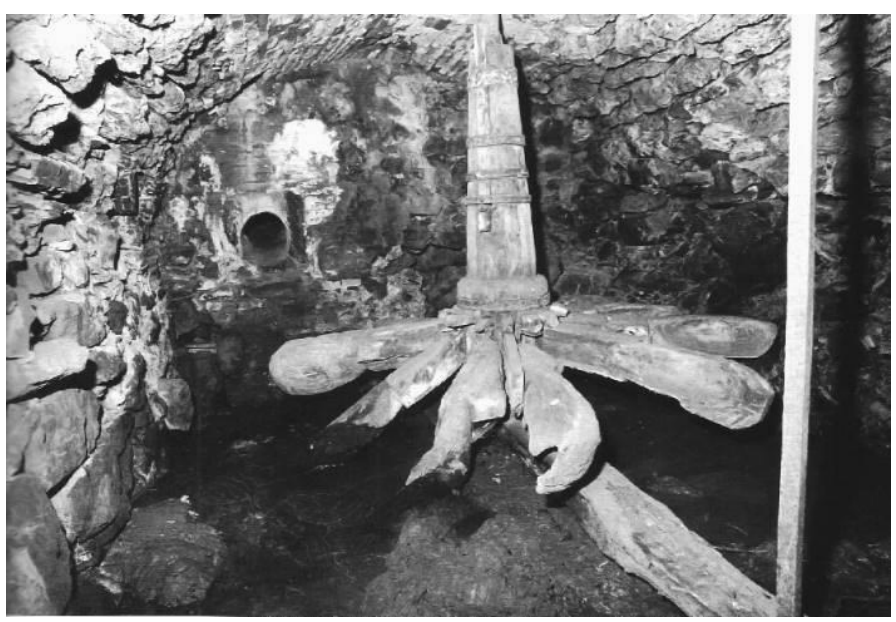

Figure 7. Waterwheel chamber of the Orzali mill: the scooped blades of the horizontal wheel were turned by the jet of water issuing under pressure from the pipe, Rio nell'Elba (photo by P. Pierotti 1993).

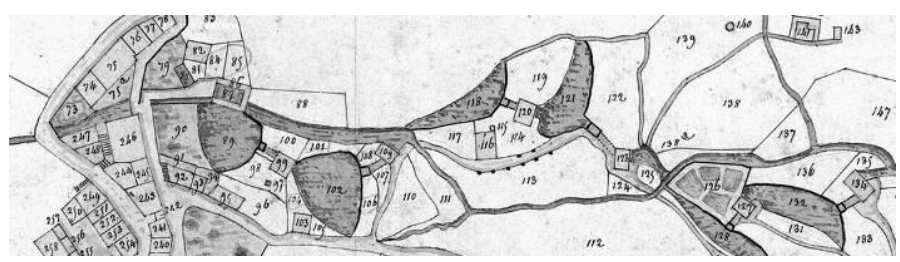

Figure 8. The ancient landscape of millponds, detail from 1824 cadastral map (Livorno State Archives, Land Registry Maps, 1587).

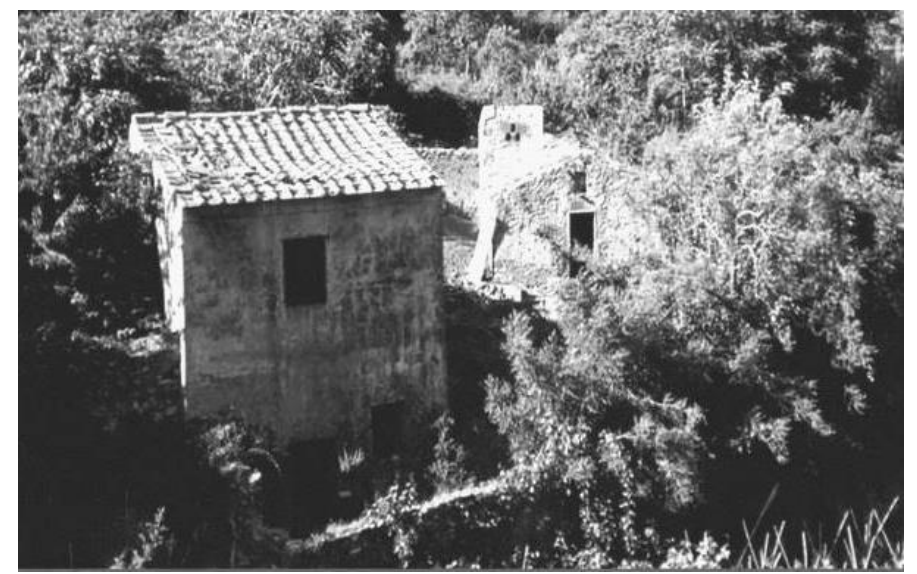

Figure 9. The Lanza millhouse and mill, Rio nell'Elba (photo by P. Pierotti 1993).

\section{REFERENCES}

Cadolini, G. 1835. L'architettura pratica dei mulini. Milano: Tipografia Fanfani.

Chini, A. 2003. Il molino dei Gangalandi. Pisa: Pacini editore.

D’Asburgo Lorena, P. L. 1970. Relazioni sul governo della Toscana. A. Salvestrini (ed.), vol. II. Firenze: L.S. Olschki.

Deri, S. 2015. Sulla via della farina, dell'olio e dei mugnai Tellini. Pisa: Pacini editore.

Gelli, A. 2014. Da Le Vene a Le Ruote. Edifizi andanti ad acqua sulle gore di Colle di Val d'Elsa. Pisa: Felici Editore.

Gelli, A. 2009. Acque vive: le gore di Colle di Val d'Elsa e gli edifici andanti a acqua. Storia Urbana 125: 133-149.

Maccari, M. 1926. Il Selvaggio. III (8): 1.

Manetti, R. 1985. Acqua passata non macina più. I mulini idraulici calcesani. Pisa: Pacini editore.

Muendel, J. 1984. The "French" mill in medieval Tuscany. Journal of Medieval History, X: 216-225.

Ninci, R. 2002. La polifunzionalità degli opifici "andanti ad acqua". Il caso di Colle Val d'Elsa. Miscellanea Storica della Valdelsa. CVIII (1-2): 151-162.

Oliver. P. (ed.) 1997. Encvclonedia of Vernacular Architecture of the World. Cambridge: Cambridge University Press.

Panduri, T. 2001. "Como acqua de mola". Mulini ad acqua nel territorio di Calci in età medievale. Pisa: Edizioni Plus.

Pierotti, P. 1982. Introduzione all'ecostoria. Milano: Franco Angeli Edizioni.

Pierotti, P. (ed.) 1993. La Valle dei Mulini. 22 mulini tra Rio Elba e Rio Marina. Guida alla storia, al percorso, al recupero. Pisa: Pacini editore.

Pierotti, P. 1999. Imparare l'ecostoria. Milano: Franco Angeli Edizioni.

Pierotti, P. \& Ulivieri, D. (ed.) 2009. Il metodo ecostorico. Pisa: Edizioni Plus.

Ulivieri, D. 2006. C'era una volta un molino. Locus 2: 55-62.

Ulivieri, D. 2009. Acque regolamentate: gli statuti delle comunità e le disposizioni dei governi. Storia Urbana 125: 5979 .

Ulivieri, D. 2015. Considerazioni sulla valle di Calci (PI): analisi di un distretto pre-industriale polifunzionale. In S. Deri, Sulla via della farina, dell'olio e dei mugnai Tellini: 9-24 Pisa: Pacini editore.

Vellinga, M. et al. 2007. Atlas of Vernacular Architecture of the World. Oxford: Routledge. Taylor \& Francis Group. 